\title{
WTO PANEL REPORT (WT/DS400/R, WT/DS401/R OF 2013) AND APPELLATE BODY REPORT (WT/ DS400/AB/R, WT/DS401/AB/R) IN EC - SEAL PRODUCTS CASE: PUBLIC MORALITY MEETS THE WORLD TRADE COURT
}

\author{
Eukasz Gruszczyński*
}

\section{Introduction}

The WTO today added fuzzy white baby seals clubbed to death on bloody ice flows to dolphins and sea turtles as animals that the WTO has declared cannot be protected by domestic laws because they violate 'trade' rules, which will just fuel public and policymaker scepticism about these so-called trade deals. ${ }^{1}$

This acerbic comment was made following the issuance by the Appellate Body of its report in a controversial dispute (i.e. European Communities - Measures Prohibiting the Importation and Marketing of Seal Products) over the European Union's (EU) marketing ban on seal products.

* PhD, Assistant Professor, Institute of Law Studies, Polish Academy of Sciences.

1 WTO Final Ruling: European Ban on Products from Inhumane Seal Harvest Violates WTO Rules, Statement of Lori Wallach, Director of Public Citizen's Global Trade Watch, available at: http://citizen.typepad.com/eyesontrade/2014/05/wto-final-ruling-european-ban-on-products-from-inhumane-seal-harvest-violates-wto-rules.html (last visited 30.1.2015). 
Does this assessment do justice to the findings of the Appellate Body? Does the law of the World Trade Organization (WTO) really prohibit its Members from protecting seals (or any other wild animals)? Is the public morals exception under WTO law just an empty shell without any normative content? The aim of this comment is to address these questions by analysing in detail the reports issued by the WTO panel and the Appellate Body in the 'Seal dispute'.

The comment proceeds as follows. The next part (Section 2) summarizes the facts of the dispute. Section 3 gives details on the reports of the WTO panel and the Appellate Body, and examines their approaches towards the EU measure. The last part (Section 4) critically assesses these approaches and attempts to ascertain the extent of regulatory freedom enjoyed by WTO Members under the public morals exception.

\section{Facts of the case}

The European Communities (EC), a predecessor of the EU, introduced its first (temporary) ban on some seal pup products in 1983. ${ }^{2}$ This ban was subsequently extended several times and eventually established as permanent. In the early 2000s some EU Member States (i.e. Belgium, the Netherlands and later Slovenia) introduced more extensive bans, while a number of others contemplated such a move. These developments, combined with the pressure from the European Parliament, prompted the European Commission to take further action at the EU level. In 2008 it published a proposal for regulation, ${ }^{3}$ the final version of which was adopted in September 2009.

The new law was immediately contested in formal proceedings in the WTO. Canada and Norway-important producers of seal products - requested

2 Council Directive No. 83/129/EEC of 28.3.1983 concerning the importation into Member States of skins of certain seal pups and products derived therefrom, OJ 9.4.1983, L 91. For more detailed discussion on the origin of the EU regulatory framework and challenges to the EU Seal Regime within the EU, see J. Beqiraj, The Delicate Equilibrium of EU Trade Measures: The Seals Case, 'German Law Journal' 2013, vol. 14, at pp. 280 et seq.

3 European Commission, Proposal for a Regulation of the European Parliament and of the Council concerning trade in seal products, 23.7.2008, COM(2008) 469 final. 
consultations with the $\mathrm{EU}^{4}$ on 2 and 5.11.2009. ${ }^{5}$ Since the consultations proved to be unsuccessful, both complainants asked for the establishment of WTO panels. This was done by the Dispute Settlement Body ("DSB" a congregation of all WTO Members responsible for the management of the dispute settlement process) in March and April 2011. At the same time, the DSB decided to merge the two proceedings and assigned the panel established at the request of Canada with the task of examining the complaint made by Norway as well. ${ }^{6}$ Since the parties could not agree on the composition of the panel, all panellists were eventually nominated by the Director General in October 2012. A number of WTO Members also joined the proceeding as third parties. ${ }^{7}$ This group included Argentina, China, Colombia, Ecuador, Iceland, Japan, Mexico, Namibia, the Russian Federation and the United States. Interestingly the complainants and the defendant agreed to make all substantive meetings with the panel open to the general public, through a closed-circuit television broadcasting of the proceedings to a separate room. ${ }^{8}$

Canada and Norway identified two specific pieces of the EU legislation (constituting for the purpose of the proceeding a single measure) as violating WTO rules:

- Regulation (EC) No. 1007/2009 of 16.9.2009 on trade in seal products ("Basic Regulation"); ${ }^{9}$

4 Consultation is an obligatory phase under the WTO dispute settlement process. The idea behind it is to give parties to a dispute a chance to reach an amicable solution (cf. Art. 4 of the Understanding on Rules and Procedures Governing the Settlement of Disputes, adopted 15.4.1994, entered into force 1.1.1995, 1869 UNTS 401 (“DSU”)).

5 Request for consultations by Canada, EC - Measures Prohibiting the Importation and Marketing of Seal Products, WT/DS400/1; Request for consultations by Norway, ECMeasures Prohibiting the Importation and Marketing of Seal Products, WT/DS401/1.

6 See, Dispute Settlement Body, Minutes of Meeting held in the Centre William Rappard on 21 April 2011, WT/DSB/M/295, 30.6.2011, para. 73. Note that such an option is provided by Art. 9 of the DSU.

7 Third parties are those WTO Members that have substantial interests in a dispute and which notify the DSB of their will to participate in the proceeding. They are entitled to make an oral and written statement to the panel. They also receive the submissions of the parties to the dispute (cf. Art. 10 of the DSU).

8 This was a very unusual move, normally all the meetings are closed to general public as the WTO proceedings is considered to be confidential.

9 Regulation (EC) No. 1007/2009 of 16.9.2009 of the European Parliament and of the Council of on trade in seal products, OJ 31.10.2009, L 286. 
- Regulation (EU) No. 737/2010 of 10.8.2010, laying down detailed rules for the implementation of the Basic Regulation ("Implementing Regulation"), ${ }^{10}$ both of which are referred to together as the "EU Seal Regime".

As noted above, the EU Seal Regime was adopted in response to public concerns about the animal welfare aspects of the killing and skinning of seals in a way that causes pain, distress, fear and other forms of suffering to those animals. ${ }^{12}$ It establishes a comprehensive ban on the placing of seal products (understood broadly as processed or unprocessed products deriving or obtained from seals, such as meat, fur skins or clothing) on the EU market. It also envisages three exceptions. The most important exception relates to seal products that result from hunts traditionally conducted by the Inuit and other indigenous communities and which, at the same time, (i) contribute to their subsistence (Art. 3.1 of the Basic Regulation), and (ii) are at least partly used, consumed or processed within the communities according to their traditions (Art. 3(1)(b) of the Implementing Regulation). This exception is referred to as the "IC hunts exception". Both groups are defined by the EU Seal Regime and include communities residing in different countries, also outside the EU. ${ }^{13}$ The second exception covers those seal products that result (as by-products) from hunts undertaken solely for the purpose of sustainable management of marine resources (in accordance with national or regional management plans). In order to qualify for this exception, such products can be placed on the market only on a nonprofit basis and their quantity cannot suggest that they are marketed for commercial reasons (referred to as the "MRM hunts exception"). ${ }^{14}$ The EU Seal Regime also provides that the eligibility of seal products for 'exceptions' status is established on the basis of documents which are issued by a relevant body in a country of export. Such a body needs to be recognized

10 Commission Regulation (EU) No. 737/2010 of 10.8.2010 laying down detailed rules for the implementation of Regulation (EC) No. 1007/2009 of the European Parliament and of the Council on trade in seal products, O.J. 17.8.2010, L 216.

11 Norway also identified the following measure as being inconsistent with WTO law: "omissions to adopt adequate procedures for establishing that seal products conforming to the relevant conditions, set forth in exceptions in the EU seal regime, may be placed on the EU market" (cf. Panel Report, EU - Seal Products, para. 2.4). The panel considered it to be a part of the measure (or its application).

12 Recital no. 5 of the preamble of the Basic Regulation.

13 Art. 2.4 of the Basic Regulation and Art. 2.1 of the Implementing Regulation.

${ }^{14}$ Art. 3.2(b) of the Basic Regulation and Art. 5 of the Implementing Regulation. 
by the Commission and included on a special list (Arts. 6 and 7 of the Implementing Regulation). Finally, the EU Seal Regime allows for the importation (but not placing on the market) of seal products brought to the EU for the personal use of travellers or their families, however only if the nature and quantity of such goods indicates that they are not imported for commercial reasons (referred to as the "Travellers imports exception"). ${ }^{15}$

Canada and Norway claimed that the EU Seal Regime was inconsistent with certain obligations of the General Agreement on Tariffs and Trade ("GATT 1994") ${ }^{16}$ and the Agreement on Technical Barriers to Trade ("TBT Agreement"). ${ }^{17}$ With respect to the GATT, both parties argued, among the other things, that the IC and MRM hunts exceptions violated Arts I:1 and III:4 because imported products from Canada and Norway were accorded less favourable treatment as compared to like EU products (mainly from Sweden and Finland), as well as other foreign products (e.g. from Greenland, which was regarded as separate custom territory). They also claimed that all three exceptions constituted quantitative restrictions that were incompatible with Art. XI:1 of the GATT 1994. As far as the TBT Agreement is concerned, Canada claimed that the EU Seal Regime violated the national treatment and most-favoured-nation principles as embodied in Art. 2.1 (on the same grounds as in the case of Art. I:1 and III:4 of the GATT 1994). In addition, both parties argued that the EU measure was more trade restrictive than necessary to fulfil a legitimate objective and therefore infringed Art. 2.2 of the TBT Agreement.

The EU rejected these claims. It maintained that its measure was compatible with both Arts. I:1 and III:4 of the GATT 1994, and that even if there were any inconsistencies they were justified under the general exceptions of Art. XX because the measure was necessary to protect public morals (subparagraph (a)). With respect to claims made under the TBT Agreement, the EU argued that the agreement was inapplicable to the dispute and in any case that the distinctions made under the EU Seal Regime between IC/MRM and commercial hunts were legitimate and therefore the measure did not violate Art. 2.1. The EU also added that its Seal Regime was necessary to achieve the objective sought by the Union and no other

15 Art. 3.2(a) of the Basic Regulation and Art.4 of the Implementing Regulation.

16 General Agreement on Tariffs and Trade 1994, adopted 15.4.1994, entered into force 1.1.1995, 55 UNTS 194, 1867 UNTS 187.

17 Agreement on Technical Barriers to Trade, adopted 15.4.1994, entered into force 1.1.1995, 1868 UNTS 120. 
less-trade restrictive measures were available, and hence it was compatible with Art. 2.2 of the TBT Agreement.

\section{Reports of the panel and the Appellate Body}

\subsection{Panel report}

The panel issued its final report on $8.10 .2013 .{ }^{18}$ Following the usual practice of the WTO case law (lex specialis rule understood as determining the sequence of examination), it decided to address the claims made under the TBT Agreement first (as the agreement is more specific and detailed) and only afterwards to address the claims made under GATT $1994 .{ }^{19}$ It found that the EU Seal Regime indeed constituted a technical regulation and therefore the TBT Agreement was applicable. ${ }^{20}$ In particular, the panel held that the EU measure laid down product characteristics (which was the only factor disputed by the parties that was relevant for finding the applicability of the TBT Agreement) in a negative form by requiring all products not to contain seal, unless such products fall within one of the exceptions. ${ }^{21}$

The panel applied, under Art. 2.1, ${ }^{22}$ a standard three-step test that requires identification of the following elements: (i) whether two products (domestic v. imported, imported v. imported) are like; (ii) whether a measure accords less favourable treatment to a group of like imported products; and (iii) whether the detrimental impact on imports stems exclusively from a legitimate regulatory distinction or rather reflects discrimination against

18 Panel Report, European Communities - Measures Prohibiting the Importation and Marketing of Seal Products, 25.11.2013, WT/DS400/R, WT/DS401/R.

19 Ibidem, para. 7.69.

$20 \quad$ Ibidem, para. 7.125.

21 Ibidem, para. 7.111; according to the panel such understanding followed the approach taken by the Appellate Body in European Communities - Measures Affecting Asbestos and Asbestos-containing Products, WT/DS135/AB/R, 12.3.2001.

22 The relevant part of Art. 2.1 provides: "Members shall ensure that in respect of technical regulations, products imported from the territory of any Member shall be accorded treatment no less favourable than that accorded to like products of national origin and to like products originating in any other country." 
a group of imported products. Against this conceptual framework, the panel found that imported and domestic seal products were indeed like. ${ }^{23}$ It also held that since most of the seals hunted in Canada did not benefit from the exceptions provided in the EU Seal Regime (nor could it in the future due to the structure of Canadian hunts, which primarily consisted of commercial hunts), while the majority of products from Greenland and the EU (mainly from Sweden, Finland and the United Kingdom) were exempted or likely to be exempted either under the IC or MRM hunts exception ${ }^{24}$, the measures thus accorded less favourable treatment to the Canadian exports. ${ }^{25}$ As regards the third element, although the panel found that the distinction between IC and commercial hunts was justifiable (as the first category is embedded in the tradition and culture of Inuit and such hunts are undertaken to sustain their livelihood), it also concluded that the EU Seal Regime was neither designed nor applied in an even-handed manner (as de facto the IC hunts exception was only available to Greenland, and the hunts undertaken by Inuit in Greenland expressed a significant similarity to commercial hunts). As a consequence, this part of the measure was held to be incompatible with Art. 2.1. ${ }^{26}$ The same conclusion was reached with respect to the MRM hunt exception. In particular the panel determined that the distinction was not justifiable because the purpose of the MRM hunts and commercial hunts was of a similar nature. ${ }^{27}$ On the other hand, the panel found that the EU Seal Regime did not violate Art. $2.2^{28}$ of the TBT Agreement because its objective was legitimate (i.e. addressing the EU public moral concerns on seal welfare), and the measure was found to be capable of making some contribution to the EU objective (and indeed did so). At the same time, the panel held that the complainants were not

23 Panel Report, EC - Seal Products, para. 7.140.

24 Most of the seal products originating from Greenland qualify for the IC exception as hunts are done there by Inuit ( $90 \%$ of the population). Due to the small amount of seals hunted under the MRM exception it is geographical proximity that privileges the EU-originating seals.

25 Panel Report, EC - Seal Products, para. 7.168.

${ }^{26}$ Ibidem, para. 7.319.

27 Ibidem, para. 7.344.

28 Art. 2.2 stipulates: "Members shall ensure that technical regulations are not prepared, adopted or applied with a view to or with the effect of creating unnecessary obstacles to international trade. For this purpose, technical regulations shall not be more trade-restrictive than necessary to fulfil a legitimate objective, taking account of the risks non-fulfilment would create. [...]" 
able to identify alternative measures that would make an equivalent or greater contribution to the fulfilment of the objective and which would be reasonably available. ${ }^{29}$ In particular, two alternatives indicated by the complainants (i.e. providing market access for products that would meet certain animal welfare standards, and certification and labelling requirements) were found to not to be reasonably available due to, e.g., difficulties in terms of monitoring and compliance. The panel also doubted whether they would provide an equal contribution to the achievement of the EU objective.

As far as the GATT 1994 was concerned, the panel held that the EU measure violated Art. I:1. ${ }^{30}$ It repeated its finding that all seal products were like. It also noted that the EU Seal Regime gave a benefit, under the IC hunts exception, in the form of market access to products originating from Greenland, without according the same conditions for products from Canada and Norway. ${ }^{31}$ As a consequence, the panel found that the measure was de facto discriminatory. Following similar logic, the panel came to the same conclusion with regard to Art. III:4, finding that imported products were, under the MRN exception, discriminated against as compared to domestic like products. Neither was the panel persuaded that the EU Seal Regime could be justified under the general exception of Art. XX. ${ }^{32}$ Although the panel found that the measure was necessary to protect public morals, ${ }^{33}$ it also held, for the same reasons as detailed above in the context of Art. 2.1, that the IC and MRM exceptions were not designed and applied

29 Panel Report, EC - Seal Products, para. 7.504.

30 Art. I:1 provides, in relevant part, that "[w]ith respect [...] to all rules and formalities in connection with importation and exportation, and with respect to all matters referred to in paragraphs 2 and 4 of Article III, any advantage, favour, privilege or immunity granted by any [Member] to any product originating in or destined for any other country shall be accorded immediately and unconditionally to the like product originating in or destined for the territories of all other [Members]."

${ }_{31}$ Panel Report, EC - Seal Products, para. 7.600.

32 Art. XX provides: "[s]ubject to the requirement that such measures are not applied in a manner which would constitute a means of arbitrary or unjustifiable discrimination between countries where the same conditions prevail, or a disguised restriction on international trade, nothing in this Agreement shall be construed to prevent the adoption or enforcement by any contracting party of measures: (a) necessary to protect public morals [...]"

33 The necessity analysis involves a process of weighing and balancing three factors: (i) the extent of the contribution to the achievement of a measure's objective; (ii) its trade restrictiveness; and (iii) the importance of the interests or values at stake (cf. e.g. 
in an even-handed manner and hence the measure was inconsistent with the requirements of the chapeau of Art. XX (an introductory part), and consequently could not be justified under this provision. ${ }^{34}$

\subsection{Appellate Body report}

All three parties decided to appeal certain aspects of the panel report. The Appellate Body issued its report ${ }^{35}$ on 22.5.2014. It reversed the panel's finding on the qualification of the EU measure as a technical regulation. In particular, it found that the EU Seal Regime did not lay down any product characteristics as required by Annex 1.1, i.e. a provision that determines the applicability of the TBT Agreement. The Appellate Body characterized the EU measure not as a prohibition (which in principle could be regarded as a form of product characteristics expressed in negative terms) but rather as a measure that sets certain conditions for placing seal products on the market (as provided under the exceptions). All those conditions related to the identity of the hunter and the purpose of the hunt, none of which could be viewed as prescribing product characteristics. ${ }^{36}$ This conclusion (that the TBT Agreement was inapplicable) meant that all the panel's findings with respect to the provisions of that agreement were held to be moot and without legal effect. ${ }^{37}$

On the other hand, the Appellate Body upheld the panel's finding that the measure violated Art. I:1 of the GATT 1994, as it modified the conditions for competition between like products originating from different

Appellate Body Report, Brazil - Measures Affecting Imports of Retreaded Tyres, 5.9.2011, WT/DS332/AB/R, para. 156.

${ }^{34}$ Panel Report, EC - Seal Products, para. 7.651. For a critical assessment of the panel report see R. Howse, J. Langille, K. Sykes, Written Submission of Non-Party Amici Curiae, 11.2.2013, available at http://www.worldtradelaw.net/amicus/howsesealsamicus.pdf. download (last visited 24.1.2015).

35 Appellate Body Report, European Communities - Measures Prohibiting the Importation and Marketing of Seal Products, 22 May 2014, WT/DS400/AB/R, WT/DS401/AB/R.

${ }^{36}$ Ibidem, para.5.45 and 5.58. This fact distinguished the Seal case from EC-Asbestos, where the measure prohibited importation of products on the basis of presence of asbestos in such products.

37 Ibidem, para. 5.70 . 
countries. ${ }^{38}$ The Appellate Body confirmed that the EU Seal Regime constituted de facto discrimination that was prohibited by the GATT rules. ${ }^{39}$ The Appellate Body also shared the panel's position that the EU Seal Regime was necessary to protect public morals (as provided by Art. XX(a)). In this context, it confirmed that the measure sufficiently contributed to the achievement of the objective sought by the EU through its Seal Regime (i.e. "addressing public moral concerns relating to the EU public's participation as consumers in the market for products derived from inhumanely killed seals" and "addressing public moral concerns relating to the number of inhumanely killed seals" ${ }^{40}$ ), and further found that the alternatives identified by the complainants could not have been regarded as reasonably available. It also rejected the claim made by Canada that the EU was required to act consistently when setting the level of animal welfare for various animals (e.g. seal hunts v. slaughterhouses or terrestrial wildlife hunting). According to the Appellate Body, Art. XX(a) did not require WTO Members to regulate similar public moral concerns in similar ways. ${ }^{41}$

Although, the Appellate Body reversed the panel's findings under the chapeau (as it disagreed with the legal test applied by the panel), ultimately it held that the EU measure failed to meet the relevant requirements of the introductory part of Art. XX. In particular, it found that several features of the EU Seal Regime led to arbitrary or unjustifiable discrimination between Canada and Greenland. According to the Appellate Body, the EU, as the party which bore the burden of proof, failed to show how the distinction between IC and commercial hunts was related to the objective of addressing EU public moral concerns regarding seal welfare. In addition, the Appellate Body was troubled with the ambiguities inherent in the criteria used for the IC exception (i.e. the exact meaning of such terms as "subsistence" and "partial use") and the extent of the discretion enjoyed by a certifying authority in an exporting country. If found that these two elements could easily lead to a situation when "seal products derived from what should in fact be properly characterized as 'commercial' hunts could potentially enter the EU market under the IC exception." ${ }^{42}$ In addition, the EU did not

38 Note that the EU did not appeal panel's finding on the violation of Art. III:4 of the GATT 1994.

${ }^{39}$ Appellate Body, EC - Seal Products, para. 5.95.

40 Ibidem, paras.5.223 and 5.225.

41 Ibidem, para. 5.200 .

42 Ibidem, para. 5.338. 
identify actions which would be taken in order to prevent shortcomings in the implementation of those rules. To top it off, the Appellate Body also held that the EU did not made sufficient efforts to facilitate the access of Canadian Inuit products to the EU market. ${ }^{43}$ Consequently, it concluded that overall the EU Seal Regime was not justified under Article XX of the GATT 1994. The same conclusions were reached with respect to Norway.

The reports of the panel and the Appellate Body were adopted by the DSB on 18.6.2014. At the beginning of September 2014, the parties informed the DSB that they had agreed on a reasonable period of time for implementation of the recommendations. According to their agreement that period expires on 18.10.2015.

\section{Comment}

The reports of the panel and the Appellate Body, although sometimes lacking the clear reasoning that would make them accessible to the broader public, ${ }^{44}$ definitely constitute an important step in the development of WTO case law. ${ }^{45}$ They elaborate on the public morals exception, a clause which until now has received only limited attention from the WTO dispute settlement bodies. ${ }^{46}$ By doing so, they provide some additional guidance as

43 Ibidem.

44 For more on this aspect of the reports, see G. Shaffer \& D. Pabian, The WTO ECSeal Products Decision: Animal Welfare, Indigenous Communities and Trade, University of California, School of Law, Legal Studies Research Paper Series No. 2014-69 (forthcoming in American Journal of International Law (2015)), at pp. 7-8.

45 For an interesting analysis of the Appellate Body report with respect to the relationship between the GATT 1994 and the TBT Agreement and the product-related/ non-product-related distinction, see G. Marceau, A Comment on the Appellate Body Report in EC - Seal Products in the Context of the Trade and Environment Debate, "Review of European, Comparative and International Environmental Law" 2014, vol. 23, no 3, p. 318. For a more general discussion of the issue, see C.R. Conrad, Processes and Production Methods (PPMs) in WTO Law: Interfacing Trade and Social Goods, Cambridge University Press, Cambridge, 2011.

46 There are two other cases that address the problem of public morals as a ground for justifying otherwise WTO-inconsistent measures (cf. Appellate Body Report, United States - Measures Affecting the Cross-Border Supply of Gambling and Betting Services, WT/DS285/AB/R, adopted 20.4.2005 and Appellate Body Report, China-Measures Affecting Trading Rights and Distribution Services for Certain Publications and Audiovisual Entertainment Products, WT/DS363/AB/R, adopted 19.1.2010). 
to the limits of the regulatory freedom enjoyed by WTO Members under the GATT 1994 when restricting international trade for moral or ethical reasons. In addition, the panel's report for the first time explicitly recognized public morals as a possible justification for trade restrictive technical regulations under the TBT Agreement. ${ }^{47}$ Hence it is worth examining some of the specific findings of both dispute settlement bodies.

At the outset, it should be stressed that the EU Seal Regime was found to violate WTO rules not because of its rationale (i.e. prioritizing the protection of public morals over trade interests) or the level of its restrictiveness, but due to operation of the exceptions that de facto privileged domestic and some imported products (in particular from Greenland) over their counterparts originating from Canada and Norway. The report of the Appellate Body clearly indicates that a complete ban on seal products would sustain WTO scrutiny. In this sense environmental groups can regard the outcome of the dispute as their victory. WTO law does not oppose non-discriminatory measures aimed at addressing animal welfare concerns. On the other hand, the EU measure was eventually struck down by both the panel and the Appellate Body. Depending on the implementation scenario (see my comments below), the reports may cause the EU to withdraw its measure. This in turn will negatively affect the animal welfare status of seals and could be regarded as a defeat for environmental concerns in the WTO framework. ${ }^{48}$

When discussing the contours of the assessment undertaken by the WTO dispute settlement bodies with respect to the public morals justification, the panel as well as the Appellate Body started with definition of the term. Public morals were understood, in line with the previous case law, as "standards of right and wrong conduct maintained by or on behalf of a community or a nation." 49 Their content is not absolute and may "vary in time and space, depending upon a range of factors, including prevailing

47 Although the Appellate Body reversed the panel's finding on the applicability of the TBT Agreement (and as a consequence did not review the specific conclusions reached by the panel with respect to TBT provisions), there would seem to be little doubt that the Agreement covers moral concerns.

48 The panel acknowledged that the EU Seal Regime has a considerable influence on the size of the global market for seal products. Since the demand for such products fell dramatically after the introduction of the Regulations, this also affected the number of seals killed every year (cf. Panel Report, EC - Seal Products, para. 7.449).

49 Ibidem, para. 7.380. 
social, cultural, ethical and religious values." ${ }^{50}$ Consequently, public morals may legitimately differ between WTO Members and there is no a need for a panel to determine their universal character nor that they are shared by complainants. In addition, it is for each WTO Member to determine the level of protection with respect to a specific moral concern that it considers appropriate. This subjective character of public morals means that a panel is expected to remain quite deferential when assessing the existence and scope of a public moral justification. Last but not least, both the panel and the Appellate Body recognized the issue of animal welfare as a type of moral concern covered by relevant WTO provisions, a recognition made for the first time in the history of the organization. As noted by Shaffer and Pabian, such recognition may have far-reaching systemic implications, providing support for various measures that restrict trade due to animal welfare concerns (e.g. a marketing ban on cosmetics tested on animals, meat and other products from animals raised in small cages, etc.). ${ }^{51}$ However, if one generalizes the findings of the dispute settlement bodies, the consequences may go even further than animal welfare. Both reports indicate that a public moral exception can be also used to justify restrictions connected with the protection of certain human rights (e.g. moral concerns connected with child labour or working conditions in some developing countries) or environmental protection requirements (e.g. moral concerns connected with protection of endangered species in the production processes that take place in an exporting country).

According to the panel, the initial analysis of the public morals defence involves two steps: (i) whether the specific concern exists in the particular society, and (ii) whether such a concern falls within the scope of public morals. ${ }^{52}$ The first element may be determined solely on the basis of the content of a contested measure, e.g. by looking at its preamble and legislative or regulatory history. It appears that there is no need for a public survey which would objectively confirm the existence of a specific moral or ethical conviction in a particular society. ${ }^{53}$ As regards the second element, it can be ascertained through reference to actions taken in the past to address specific moral issues, existing legislation, and international legal

50 Ibidem.

51 Shaffer \& Pabian, The WTO EC-Seal Products Decision..., p. 1.

52 Ibidem, para. 7.383.

53 Ibidem, para. 7.398. 
instruments applicable in the country(-ies) concerned. Again the threshold here seems to be relatively low.

The Appellate Body supplemented these findings with the observation that there is no need for a panel to identify the existence of any risk to the specific public moral concerns which a particular measure seeks to protect. ${ }^{54} \mathrm{~A}$ panel is not required to "identify the exact content of the public morals standard at issue", 55 and a general description is sufficient. As already noted above, the Appellate Body also made clear that WTO Members are not expected to address the same or similar moral concerns in a consistent fashion (e.g. to establish the same welfare standards for wild and domestic animals). This finding contrasts with the approach taken by the WTO dispute settlement bodies under the Agreement on the Application of Sanitary and Phytosanitary Measures ${ }^{56}$ ("SPS Agreement"), where a certain degree of consistency is required for health and safety regulations. This seems to be a sensible approach. Neither GATT Art. XX nor the TBT Agreement contain language comparable to Art. 5.5 of the SPS Agreement. ${ }^{57}$ Consequently, on the textual level it would be difficult to argue that Art XX(a) implicitly requires WTO Members to ensure a certain level of consistency. Moreover, moral convictions, being very context-oriented, are hardly susceptible to uniformity standards (e.g. ethical standards with respect to certain animals such as seals or dolphins seems to be higher than for most farm animals; the same is true with respect to an acceptable level of protection in use of animals for cosmetic testing as compare to testing undertaken as a part of medical research). A consistency requirement, even if formulated in flexible terms (e.g. preventing only unjustifiable forms of

54 Appellate Body, EC - Seal Products, para.5.198. Canada had specifically argued that evidence has to show that "the commercial seal hunts targeted by the ban exhibit a degree or incidence of animal suffering that falls below the standard or norm of right and wrong conduct in the context of animal welfare shown to prevail within the [European Union]" (ibidem, para. 5.194).

55 Ibidem, para.5.199.

56 Agreement on the Application of Sanitary and Phytosanitary Measures, adopted 15.4.1994, entered into force 1.1.1995, 1867 UNTS 493.

57 Art. 5.5 provides, in relevant part: "[w]ith the objective of achieving consistency in the application of the concept of appropriate level of sanitary or phytosanitary protection against risks to human life or health, or to animal and plant life or health, each Member shall avoid arbitrary or unjustifiable distinctions in the levels it considers to be appropriate in different situations, if such distinctions result in discrimination or a disguised restriction on international trade." 
inconsistency) could also put into question the right of each Member to determine the level of protection that it deems appropriate.

Overall, as the above analysis shows, both the panel and the Appellate Body seem to be quite sensitive with respect to the conduct of WTO Members motivated by public moral and ethical concerns, recognizing a need for plurality. Such an approach should definitely be considered a positive development.

Of course it may be argued that the generous standards proposed by the WTO dispute settlement bodies may result in abuses of the public morals exception for protectionist purposes. ${ }^{58}$ Although such a risk cannot be entirely eliminated, arguably it was partially mitigated by number of observations made by the Appellate Body. First, while in principle the WTO dispute settlement bodies remain very deferential when it comes to assessment of the existence and content of specific moral concerns, they still require that a measure be rationally related to an identified moral objective (under the necessity requirement). Such a measure also needs to pass the test of the chapeau. A panel is expected to examine whether the discrimination is rationally related to a specific policy objective (although the Seal Products report shows that this is not a decisive criterion); assess the precision of the criteria used for distinguishing one group of products from another; check whether the measure is applied in a fair and just manner; and verify whether a defendant has made comparable efforts to reach a mutually acceptable solution for all affected countries. ${ }^{59}$ These conditions definitely restrict the space for potential abuses.

Second, the Appellate Body also highlighted that there might be some jurisdictional limitation implied in Art. XX(a). Although ultimately it did not make any findings in this regard (as the parties to the dispute did not advance this issue), it referred to one of its previous reports (US - Shrimp Products ${ }^{60}$ ), which suggests that there needs to be some (sufficient) nexus between a regulating country and an object of regulation (in casu endangered marine populations and the United States). ${ }^{61}$ This reservation echoes

58 For a similar concern, see C. Flores Elizondo, Case Review: European Communities Measure Prohibiting the Importation and Marketing of Seal Products, "Manchester Journal of International Economic Law” 2014, vol. 11, no 2, p. 312, at p. 320.

59 Note however that this part of the analysis presented by the Appellate Body remains quite general and does not give WTO Members clear guidance for the future.

60 Appellate Body Report, United States - Import Prohibition of Certain Shrimp and Shrimp Products, WT/DS58/AB/R, 6.11.1998.

${ }^{61}$ Appellate Body Report, EC - Seal Products, para. 5.173. 
the old and unresolved debate in GATT/WTO law on permissibility of socalled "extra-territorial measures" that aim at influencing the behaviour of another WTO Member with respect objects or situations located within the territory of such a Member. While some authors believe that WTO Members are prohibited from regulating in such instances, others argue that "extra-territorial measures" are in principle permissible and are subject to normal WTO disciplines. ${ }^{62}$

It is clear from the Appellate Body report that WTO Members can legitimately regulate moral concerns that are connected with conduct located outside the territory of such a Member. This was actually the case in the EC - Seal Products dispute, where the EU was concerned with hunts (and more specifically with the identity of hunters and purpose of those hunts) taking place not only within the Union but also outside of its territory. In this sense, the Appellate Body seems to take the side of the proponents of a more liberal interpretation of the relevant WTO provisions. However it may be argued (persuasively in my opinion) that there is no extra-territorial dimension in the EU Seal Regime at all. As noted by the WTO dispute settlement bodies, the measure was aimed at addressing public moral concerns within (and not outside) the EU with respect to seal hunts. ${ }^{63}$ This appears to be a characteristic feature of national measures based on public moral considerations. In most cases they are concerned with certain moral convictions held by citizens of a particular country. As correctly noted by Howse and Regan, "as long as the importing country regulates directly only behaviour within (or at) its borders, then it is not regulating extra-territorially even if its goal is to avoid encouraging behaviour beyond its borders." ${ }^{64}$ This aspect seems to distinguish that group of measures

62 See, e.g., Ch. Feddersen, Focusing on Substantive Law in International Economic Relations: The Public Morals of GATT's Article XX(a) and “Conventional” Rules of Interpretation, "Minnesota Journal of Global Trade", 1998, vol. 7, at p. 75 (for the first position); S. Bal, International Free Trade Agreements and Human Rights: Reinterpreting Article XX of the GATT, "Minnesota Journal of Global Trade" 2001, vol. 10, at p. 62; S. Charnovitz, The Moral Exception in Trade Policy, "Virginia Journal of International Law" 1998, vol. 38, at p. 689 (for the second position).

${ }_{63}$ For a similar argument, see also M. A. Young, Trade Measures to Address Environmental Concerns in Faraway Places: Jurisdictional Issues, "Review of European, Comparative and International Environmental Law" 2014, vol. 23, no 3, p. 302, at p. 303.

64 R. Howse \& D. Regan, The Product/Process Distinction: An Illusory Basis for Disciplining "Unilateralism" in Trade Policy, "European Journal of International Law" 2000, vol. 11, no 2, p. 249, at p. 278. 
from those which are aimed at protection of the environment. As far as the latter is concerned, it is not difficult to imagine a purely extra-territorial regulation without a local component, e.g. a measure protecting an endangered species or rain forest located in another country.

If Art. XX(a) indeed requires some nexus, ${ }^{65}$ such a connection should be of a product-related rather than a territorial character. As noted above, any territorial nexus would make little sense with respect to a public morals justification (contrary to other subparagraphs of Art. XX of the GATT 1994). What can be relevant is whether a particular moral or ethical concern in an importing country is directly related to a specific good, or rather concerns more broadly a situation in an exporting state. The EU Seal Regime falls within the first category as it aims at prohibiting the access to the EU market of seal products (subject to certain exceptions) which are derived from hunts, many of which involve the inhumane killing of seals. Therefore the relation between the moral concerns in the EU and the products at hand remains relatively close. On the other hand, measures which prohibit or condition the market access of products due to moral concerns relating to a general situation in an exporting country (e.g. overall poor enforcement of labour rights relating to employment of minors, e.g. employment of children in factories producing clothes) will have a weaker (and more indirect) connection to the regulated goods. Such a measure would seem to be concerned more with changing policy in the exporting country (thus encroaching more directly on the sovereignty of another state) than addressing national public moral concerns relating to the participation of local consumers in the market of regulated goods. However, taking into consideration the enigmatic observations of the Appellate Body, it is yet to be seen whether this will be the approach taken by the WTO dispute settlement bodies in the future.

Finally, it is worth looking at the compliance options that are available to the EU following issuance of the reports. The two primary ones would be either removal of the ban and allowing unrestricted trade in seal products, or tightening the ban by withdrawing the currently available exceptions.

65 Note that such a connection was required with respect to measures relating to the conservation of exhaustible natural resources. The Appellate Body in US - Shrimp Products found that turtles were a migratory species that pass through the territorial waters of the United States. According to the Appellate Body, this fact was sufficient to find a jurisdictional nexus between that country and the object of the protection (see Appellate Body Report, US - Shrimp Products, para. 133). 
Neither of these options seem to be politically feasible. Removal of the ban will be strongly opposed by the general public and non-governmental environmental organizations. It is also doubtful whether such a move would find a sufficient support in the European Parliament (required to amend the regulations), inasmuch as the EP overwhelmingly voted for the adoption of the Basic Regulation. On the other hand, tightening the ban will not only be unacceptable for certain EU Member States (particularly Denmark, due to its connections with Greenland) but may produce certain reputational costs for the $\mathrm{EU}$ in terms of disrespecting the rights of indigenous populations. Such a move could be seen as yet another example of the paternalistic approach of the EU and may be incompatible with the obligations held by EU Member States under various international instruments protecting the rights of indigenous people. ${ }^{6}$

A third option for the EU would be to simply refuse to comply with the reports and face retaliation from both complainants. Although the DSU provides that prompt compliance with the recommendations is an obligation of each WTO Member and is essential for the effective functioning of the whole international trade system (Art. 21.2 of the DSU), it also accepts compensation and suspension of concessions or other obligations as "temporary measures available in the event that the recommendations and rulings are not implemented within a reasonable period of time." ${ }^{67}$ Considering that the size of the trade affected by the ban is insignificant from the perspective of the entire EU economy, this would be a rather painless decision in economic terms, although it would also have consequences in terms of reputational costs and may impact on the bilateral relations with both trading partners. It should be noted that such a decision would not be a complete novelty for the European Union. For example, the EU for a long time refused to withdraw the ban on hormone-treated beef despite the clear recommendations to the contrary made by the panel and the Appellate Body. ${ }^{68}$

A fourth, and perhaps the most probable, option would be modification of the EU measure in order to address the concerns raised by

${ }_{66}$ For more on this aspect, see K. Hossain, The EU ban on the import of seal products and the WTO Regulations: Neglected human right of the Arctic indigenous peoples?, "Polar Record" 2013, vol. 49, no 2, at p. 154.

${ }^{67}$ Art. 22.1 of the DSU.

${ }_{68}$ Cf. Appellate Body Report, EC Measures Concerning Meat and Meat Products (Hormones), WT/DS26/AB/R, WT/DS48/AB/R, adopted 13.2.1998. 
the Appellate Body. In particular this should include clarification of the ambiguous terms and conditions under the IC exception (such as "subsistence" and "partial use"), improvements in the supervision over decisions taken by certifying authorities in the countries of export, as well as taking actions that would facilitate the access of Canadian and Norwegian Inuit products to the EU market. There are indeed some initial signs that this will be the preferred compliance option (not only for the EU but also for the complainants). In October 2014, the EU and Canadian high officials announced that they were working on a new regulatory framework that, when implemented, will enable Canadian indigenous seal products to be exported to the EU. ${ }^{69}$ Seal products that come from purely commercial hunts will be apparently left outside this framework. ${ }^{70}$ Unfortunately there is no information publicly available at this time whether similar negotiations are being conducted between the EU and Norway. What remains clear is that the Norwegian seal industry is currently going through a period of fundamental changes that may lead to its total elimination. If this scenario turns out to be true, there will a little internal pressure on the Norwegian government to retaliate against the $\mathrm{EU}$ in the event of its noncompliance with the reports. ${ }^{71}$ And this will be a full victory of animal welfare over international trade.

69 Cf. Nunatsiaq News, Canada, EU strike deal on indigenous-hunted seal products, available at http://www.nunatsiaqonline.ca/stories/article/65674canada_eu_strike_ deal_on_indigenous-hunted_seal_products/ (last visited 23.1.2015).

${ }^{70}$ Statement of the Canadian Sealers Association, CSA unhappy with EU - Canada trade deal, available at http://www.sealharvest.ca/site/?p=3368 (last visited 23.1.2015).

71 Norway scraps subsidies to seal hunters, available at http://www.thelocal. no/20141212/norway-scraps-controversial-seal-hunting-subsidy (last visited 23.1.2015). The Norwegian government decided to cut the subsidies for seal hunts, subsidies constitute about $80 \%$ of the income derived by seal hunters. 